pliers to improve product quality, and brings lower prices to the motorist. 111 Admittedly, unrestrained competition may lead to abuses. Price discrimination by a supplier may cause substantial harm to its outlets. However, proceedings under the Robinson-Patman Act and actions by the FTC should be able to meet this problem. An interpretation of the RobinsonPatman Act in the light of its original purpose to help the small independent businessman would probably be enough to protect the retailers' interest. ${ }^{112}$ The uniform withdrawal of competitive allowances should be scrutinized for possible violations of the Sherman Act. However, a "rule of reason" approach is suggested in appraising the validity of the concerted action taken by the suppliers with the burden on the suppliers to prove reasonableness. ${ }^{113}$

Trade association and purported labor union activities of gasoline retailers should be investigated. If the purpose of such organization is found to be repugnant to state or federal policy, i.e., where the concentration of selling power derived from the concerted action puts gasoline consumers in the locale in an unequal bargaining capacity for gasoline, remedies compatible with freeing competition should obtain.

\title{
ELIMINATION OF ACCRUED DIVIDENDS: POSSIBLE OBSTACLES FOR THE PENNSYLVANIA CORPORATION
}

A business corporation which has been engulfed in a protracted period of financial loss will frequently authorize and issue new common stock to obtain the fresh funds necessary to rejuvenate itself, prevent a further downward trend, and avail itself fully of the prospect for profits in the brighter period ahead. Bank loans may be either unavailable because the corporation's earning record has not been good or else undesirable because of the fixed financial burden the interest rate will place on the corporation whose future earnings are only speculative. Thus, issuance of new securities may be the only feasible way to obtain working capital. The corporation so situated may find this avenue of financing blocked by large dividend arrearages which have accrued on its cumulative preferred stock during its bleak period. Investors, otherwise willing to speculate on the company's future earnings, will be reluctant to do so where such earnings will go to the preferred shareholders for an indefinite future period. Therefore, elimination or scaling down of dividend arrearages is dictated in such situations.

111. National Petroleum News, March 5, 1950, p. 10.

112. See Austin, Price Discrimination 7 (1952).

113. For a list of factors to be considered in determining reasonableness, see Smith, Effective Competition: Hypothesis for Modernizing the Antitrust Lazes, 26 N.Y.U.L. REv. 405, 441 (1951). 
A recent decision of the Pennsylvania Supreme Court, ${ }^{1}$ defeating an attempted corporate elimination of accrued dividends on preferred stock, calls for a re-examination of the problems posed by such action. Three of these will be considered: (a) corporate power to effect the elimination; (b) the constitutional questions raised by statutes specifically authorizing the elimination; and (c) achieving fairness to the dissenting preferred shareholders where the elimination is allowed.

\section{Corporate Power}

Three methods are available to eliminate accrued dividends: (1) direct elimination by charter amendment; (2) merger and consolidation; and (3) indirect elimination by amending the charter to provide for the issuance of a new preferred, prior in dividends to the old, and allowing the preferred shareholders to surrender their stock plus accrued dividends for the new preferred. Since an amendment of the charter is necessary to effectuate any of the plans, the statutory requirements for amendment must be followed. The principal requirement is that a majority of each class of shares vote in favor of the amendment. ${ }^{2}$ The bulk of the common stockholders will, of course, agree to such an amendment, impelled by a desire to keep the corporation alive and by the knowledge that their chance for a share of the expected profits will be greatly improved by a complete or partial elimination of preferred dividend arrearages. To secure the consent of the preferred, however, it will probably be necessary to offer concessions attractive enough to induce them to relinquish their accrued dividends. These concessions will usually take the form of increasing their equity in the corporation, by increasing the par value of their preferred, while holding the dividend rate constant; or by giving them common stock in addition to their preferred, thus increasing their proportion of the annual profits. They may also be offered increased voting rights. The majority of the preferred stockholders will thus be induced to concur in such an amendment by a realization that all they have at present is a claim to doubtful future earnings of a languishing business, whereas if they surrender their claim to accrued dividends in return for a larger percentage in the equity of the corporation, they will be in a position to claim the lion's share of very probable future earnings of a revitalized corporation.

Although an overwhelming majority of the preferred shareholders may vote in favor of the elimination of arrearages by one of the above methods, indicating their belief that it is in their best interests and perhaps the best

1. Schaad v. Hotel Easton Co., 369 Pa. 486, 87 A.2d 227 (1952).

2. E.g., Pa. Stat. ANn. tit. 15, $\$ 2852-801(4), 804,902$ (c) (Purdon 1939); Onro Gen. Code ANN. \$8623-14, 15 (Page Supp. 1952) ; VA. Code tit. 13, $\S \$ 13-35$, 37 (1950). In the case of merger the statutes generally provide for a simple majority of all voting shares. However, since $a$ demand by a large number of preferred shareholders for appraisal and purchase of their shares would defeat the whole purpose of the plan, it is practically necessary to obtain the consent of the bulk of preferred shareholders. See note 3 infra. 
interest of the corporate entity, a minority may dissent and insist on the payment of their accrued dividends before any other dividends are paid by the corporation. In certain instances these dissenters have the statutory right to insist that their stock be appraised and purchased by the corporation for its fair market value. ${ }^{3}$ Even where such a remedy exists, dissenters may contend that this is not an exclusive remedy, and attempt to enjoin the operation of the plan on the ground that they have bargained for certainty of income and a preferred position over other stockholders, and that the attempted elimination violates their contract with the corporation and the other stockholders. ${ }^{*}$ The dissenting shareholder may precipitate litigation by suing to enjoin the operation of the proposed plan or seeking a declaration that as to his shares the accrued dividends must be paid before any dividend payments can be made on any shares as they exist subsequent to the consummation of the proposed plan. ${ }^{5}$

The question of whether and in what manner accrued dividends may be eliminated has been viewed by courts simply as one of power under the corporation charter, which, for this discussion, will be taken to include both the articles of incorporation and the corporation laws of the state, ${ }^{6}$ for it is here that the preferred stock contract is embodied. ${ }^{\top}$ Whether or not a dissenting preferred shareholder will succeed in his action to have a plan enjoined will depend upon whether the action proposed by the corporation is sanctioned by the corporate charter. The direct method of elimination has generally proved unavailing to the corporation on the ground that corporation statutes, which typically allow amendment of the charter to change preferences of preferred stock ${ }^{8}$ upon the vote of a majority or more of the class of shareholders involved, are not broad enough to authorize the elimination of accrued dividends. ${ }^{\circ}$ On the other hand, the merger device,

3. This remedy is usually available in cases of merger. See PA. Stat. ANN. tit. 15, \$2852-908 (Purdon 1939); DEL. REv. CoDE c. 65, \$2093.61 (1935). In Ohio the dissenter has this remedy under all three methods. See OHro GEN. CODE ANN. $\S 8623-14,15,72$ (Page Supp. 1952).

4. In general, these attempted injunctions will fail, at least in the merger or indirect methods. See notes 10,11 and 13 infra.

5. This strategy was successful in Patterson v. Durham Hosiery Mills, 214 N.C. 806,200 S.E. 906 (1939), the only case found in which such a remedy was granted.

6. DEL. REv. CODE c. $65, \S 2115$ (1935) specifically provides that the statutory provisions become part of the corporate charter. Where the corporation statutes do not so provide, court decisions have made it clear that this is so. See, for example, Beaver County Bldg. \& Loan Ass'n v. Winowich, $323 \mathrm{~Pa}$. 483, 489, 187 Atl. 481, 484 (1936).

7. Provisions in the by-laws of the corporation and in the stock certificate may also form part of the contract with the corporation.

8. See, e.g., DEL. REv. CODE c. $65, \S 2058$ (1935) allowing amendment of a charter in order to reclassify capital stock by: "Changing the . . preferences .. or other special rights of the shares. . . ."

9. Consolidated Film Industries, Inc. v. Johnson, 22 Del. Ch. 407, 197 At1. 489 (Sup. Ct. 1937) ; Keller v. Wilson \& Co., 21 Del. Ch. 391, 190 At1. 115 (Sup. Ct. 1936) ; Patterson v. Henrietta Mills, 216 N.C. 728, 6 S.E.2d 531 (1940) ; Davison v. Parker, Austin \& Liscomb, 285 N.Y. 500, 35 N.E.2d 618 (1941); Harbine v. Pioneer Mech. Corp., 65 F.2d 332 (2d Cir. 1933); Western Foundry Co. v. Wicker, Dayton Malleable Iron Co., 61 Ohio App. 1, 22 N.E.2d 281 (1939). Contra, Harr v. 
whereby a corporation with large accumulations on preferred stock merges with another corporation and, in the process of rearranging the capital structure of the two corporations, forces an exchange of the preferred plus accruals for stock in the new corporation, has been almost universally allowed. It has been permitted where the merger was between a defaulting parent corporation and a wholly-owned, inactive subsidiary 10 and even where the subsidiary was created solely for the purposes of merger. ${ }^{11}$ The rationalization has been that existing statutes authorize merger upon approval of a majority of shareholders and that a necessary and foreseeable concomitant of merger is elimination of any accrued dividends. ${ }^{12}$ The use of the indirect or optional method has been generally sanctioned by the courts ${ }^{13}$ on similar reasoning: the creation of a superior preferred stock is allowed by a statute antedating the formation of the corporation and the preferred shareholders have to bear the consequences of the exercise of this power. ${ }^{14}$

403 I11. 260, 85 N.E.2d 722 (1949). Thus only one state court of last resort has allowed elimination of accrued dividends under a statute of general wording similar to that of Delaware allowing changes in "preferences, or . . . other special rights of the shares." The Harr case, dealing with a Delaware corporation, was disapproved by the state court in Keller v. Wilson \& Co., supra. Where a statute in existence prior to formation of the corporation expressly allows elimination of accrued dividends by charter amendment, the shareholder has consented in advance to such a change and cannot complain. The situation that arises when such a statute is passed subsequent to incorporation is discussed below. 1940).

10. Federal United Corp. v. Havender, 24 Del. Ch. 318, 11 A.2d 331 (Sup. Ct.

11. Hottenstein v. York Ice Machinery Corp., 136 F.2d 944 (3d Cir. 1943).

Other cases permitting elimination by merger: Hubbard v. Jones \& Laughlin Steel Corp., 42 F. Supp. 432 (W.D. Pa. 1941) ; Windhurst v. Central Leather Co., 107 N.J. Eq. 528, 153 Atl. 402 (Ct. Err. \& App. 1931) ; Zobel v. American Locomotive Co., 182 Misc. 323, 44 N.Y.S.2d 33 (Sup. Ct. 1943).

12. This was made explicit by the court in Federal United Corp. v. Havender, 24 Del. Ch. 318, 334, 11 A.2d 331, 338 (Sup. Ct. 1940) :

"The average intelligent mind must be held to know that dividends may accumulate on preferred stock, and that in the event of a merger of the corporation issuing the stock with another corporation, the various rights of shareholders, including the right to dividends on preference stock accrued but unpaid, may, and perhaps must, be the subject of reconcilement and adjustment; for, in many cases, it would be impracticable to effect a merger if the rights attached to the shares could not be dealt with."

This reasoning would have been unchallengeable had the merger been between two separate corporations to unite their forces for more effective business operation. But the merger was between a parent corporation and an inactive subsidiary. The court could have accorded protection to accrued dividends by holding that the instant merger was merely a guise to effect a forced elimination of accrued dividends which, when attempted by direct amendment, had been forbidden by the same court in Keller v. Wilson \& Co., 21 Del. Ch. 391, 190 Atl. 115 (Sup. Ct. 1936).

13. Permitting elimination by issue of prior preferred: Johnson v. Fuller, 121 F.2d 618 (3d Cir.), cert. denied, 314 U.S. 681 (1941) ; Longson v. Beaux-Arts Apts., 265 App. Div. 951, 38 N.Y.S.2d 605 (2d Dep't 1941), aff'd, 290 N.Y. 845, 50 N.E.2d 240 (1943) ; Shanik v. White Sewing Machine Corp., 25 Del. Ch. 371, 19 A.2d 831 (Sup. Ct. 1941) ; Kreicker v. Naylor Pipe Co., 374 I11. 364, 29 N.E.2d 502 (1940); Johnson v. Lamprecht, 133 Ohio St. 567, 15 N.E.2d 127 (1938). Contra, Patterson v. Durham Hosiery Mills, 214 N.C. 806, 200 S.E. 906 (1939).

14. This reasoning was well expressed by the Chancery Court in Shanik v. White Sewing Machine, 25 Del. Ch. 154, 162, 15 A.2d 169, 173 (Ch. 1940), in commenting on two prior Delaware cases forbidding direct elimination: 
This anomalous pattern protects dividend arrearages from elimination by the simplest method but leaves them prey to more devious plans. Justification may be attempted by reasoning that in a merger the dissenting shareholder has the statutory remedy of having his shares appraised ${ }^{15}$ and purchased by the corporation, and under the indirect plan he is still preferred as to both accrued and future dividends over the common stockholders. But this rationalization does not ring true. The appraisal remedy may give the dissenter little more than he would get if he sold his stock on the open market, which he can do without benefit of statute if a direct elimination is proposed. ${ }^{18}$ As to the optional plan, the element relied on by the corporation to make it a complete success is the pressure put on the dissenters to make the exchange. If they accede, it is likely they will start to receive current dividends; if they do not, their right to accrued dividends may not be worth anything for several years since earnings may be just enough to cover dividends on the new preferred.

\section{Constitutronal Problems: The Schaad Case}

Dissatisfaction with this patchwork theory of accrued dividend elimination ${ }^{17}$ led several state legislatures to pass statutes specifically allowing the elimination of accrued dividends by charter amendment approved by a specified percentage of each class of shares. ${ }^{18}$ As a result the emphasis was shifted in this area from the question of corporate power under existing statutes to the constitutional problems of the right of the state under the power reserved in its constitution to alter corporate charters.

In light of this shift of emphasis, a recent decision of the Pennsylvania Supreme Court in Schaad v. Hotel Easton Co. ${ }^{19}$ is illuminating, not so much for its holding as for its broad dictum on the constitutional question. The corporation had been chartered in Pennsylvania in 1924. It had outstanding 7158 out of an authorized 7500 shares of $7 \%$ cumulative, nonvoting preferred stock and 3039 out of an authorized 3500 shares of no-par common stock. From its inception in 1924 through the year 1942, the corporation suffered annual losses and incurred a deficit of over $\$ 250,000$.

"Nevertheless, these cases by no means hold that language such as that of the charter of this defendant should be construed to express or imply an undertaking that accumulated dividends will in fact, and at all events, be paid; nor an undertaking that the corporation will not make changes, permitted by the statutes, in its capital structure, which may as a consequence reduce the probabilities of actual payment of the dividends."

15. See note 3 supra.

16. See Lattin, Remedies of Dissenting Shareholders Under Appraisal Statutes, 45 HaRv. L. REv. 233 (1931).

17. The decision in Harbine v. Dayton Malleable Iron Co., 61 Ohio App. 1, 22 N.E.2d 281 (1939) enjoining direct elimination was followed the same year by a legislative amendment expressly permitting such elimination. A similar decision of the New York court in Davis v. Parke, Austin \& Liscomb, 285 N.Y. 500, 35 N.E.2d 618 (1941) was followed within two years by similar action by the New York legislature. See note 18 infra.

18. N.Y. STock CoRp. LaW \$35(3); OHIo GEN. CODE ANN. §8623-14, 15 (Page Supp. 1952) ; VA. CoDE tit. 13, \$\$13-35, 37 (1950).

19. 369 Pa. 486,87 A.2d 227 (1952). 
From 1943 to 1948 it made profits resulting in a reduction of the deficit to $\$ 60,000$. No dividends had ever been paid and accruals on the preferred amounted to $\$ 157$ per share at the start of 1949. In February of that year the charter was amended to provide for an increase of common shares from 3500 to 75,000 and for a compulsory exchange of each share of preferred plus accrued dividends for 10 shares of common. Only $1 \%$ of the outstanding shares of each class voted against the amendment. ${ }^{20}$ Plaintiff, a dissenting preferred shareholder, brought suit to enjoin the corporation from proceeding with the plan. After threading its way through Pennsylvania's corporation law, the court found that the applicable statute empowered a business corporation

"To increase or diminish its authorized capital stock, or to reclassify the same by changing the number, par value, designations, preferences, or relative, particpating, optional or other special rights of the shares, or the qualifications, limitations, or restrictions of such rights, or by changing shares with par value into shares without par value ... and in any and as many other respects as desired. 21

These broad powers were qualified, however, by a provision that

"This act shall not impair or affect any . . . right accruing, accrued, or acquired . . . prior to the time this act takes effect, but the same may be enjoyed, asserted, enforced . . . as fully and to the same extent as if this act had not been passed." 22

These provisions were passed in 1933, after the corporation had been formed and the stock issued. The court indicated that the first provision might be broad enough to permit the changes attempted, but held that the second provision prevented the proposed cancellation of the arrearages.

The holding in this case appears correct under the present state of corporation law in Pennsylvania, subject to one question which was not raised by counsel in the case or specifically considered by the court. The saving clause provides that the Act ". . . shall not impair or affect any . . r right accruing, accrued, or acquired ... prior to the time this act takes effect . . ." It could be argued that arrearages attributable to the years after 1933 could be eliminated by amendment since these did not accrue prior to the time the act took effect. The answer to such an argument by the corporation, and the one inferentially adopted by the court, ${ }^{23}$ is that while some of the dividends in question did not accrue or "vest" until after 1933, the right to have unpaid dividends accumulate was acquired

20. This information is found scattered through the transcript of Record. It is collected, unopposed by any counter statement of Appellees, at pp. 8-11 of Brief for Appellants, Schaad v. Hotel Easton Co., supra note 19.

21. Pa. Stat. Ann. tit. 15, $\$ 2852-801$ (Purdon 1938).

22. Pa. Stat. Ann. tit. $15, \S 2852-5$ (Purdon 1938).

23. 369 Pa. 486, 496-497, 87 A.2d 227, 232 (1952). 
prior to 1933, and to permit elimination of post-1933 accruals would be to impair this right. Thus the court is protecting not only those rights which might be deemed "vested" but all contract rights of the shareholder. One effect of such a holding is that pre-1933 corporations are unable to eliminate the cumulative feature as to future dividends, a power which is accorded to both Delaware and New York corporations. ${ }^{24}$

The Dictum.-The holding made it unnecessary to decide the question of whether the grant of power in the first provision would be constitutional as an exercise of the state's reserve power to alter or amend corporate charters. But Justice (now Chief Justice) Stern went on to say:

". . . while there is conflict of authority on the subject, the preferable view would seem to be that this reserved power of the State to alter or amend charters of incorporation, although wide, is not unlimited, and that it can be properly exercised only to amend a charter so far as it represents a contract between the corporation and the State, and not in respects as to which it constitutes a contract between the corporation and the shareholders or between the shareholders themselves. . . . Any attempted statutory authorization of a corporation to destroy the preferential right to the accrued dividends would seem to involve either an unconstitutional deprivation of property, or an impairment of the obligation of contracts, or both, and this notwithstanding the reserved power of amendment." 25

This dictum would appear to block any attempt by the legislature to allow direct removal of accrued dividends, as well as changes in any of the other rights of stock ownership.

The neat division of the corporate charter into a contract 1 ) between the state and the corporation, 2) between the corporation and the shareholders, and 3) between the shareholders inter sese, with only the first of the three capable of being altered by the state under the reserve power, is a thesis which the writer of the opinion in the instant case had elaborated in an article published in $1905 .^{28}$ The view there expressed was that things

24. Morris v. American Public Utilities Co., 14 Del. Ch. 136, 122 At1. 696 (Ch. 1923); see McNulty v. W. \& J. Sloane, 184 Misc. 835, 845, 54 N.Y.S.2d 253, 262 (Sup. Ct. 1945).

As to the other two methods of arrearage elimination, Pennsylvania appears to be in line with the pattern prevailing in Delaware and other states. A federal court has sustained the use of the optional method by a Pennsylvania corporation, Johnson v. Fuller, 121 F.2d 618 (3d Cir. 1941), affirming 36 F. Supp. 744 (E.D. Pa. 1940), cert. denied, 314 U.S. 681 (1941) and a Pennsylvania statute permits the merger of corporations and restricts dissenting shareholders to the appraisal remedy, PA. STAT. ANN. tit. 15, $\$ 2852-908$ (Purdon 1938). Hubbard v. Jones \& Laughlin Steel Corp., 42 F. Supp. 432 (W.D. Pa. 1941) permitted the elimination of accrued dividends in connection with the merger of a parent corporation and two wholly owned subsidiaries.

25. 369 Pa. 486, 497-498, 87 A.2d 227, 232 (1952).

26. Stern, The Limitations of the Power of a State under a Reserved Right to Amend or Repeal Charters of Incorporation, 53 Ax. L. REG. 1-47, 73-111, 145169 (1905). 
affirmatively granted to the corporation by the state-such as the franchise itself or exception from general taxation-could be reached by the reserve power, ${ }^{27}$ but that matters agreed upon by the shareholders among themselves and with the corporate entity, such as division of profits and voting rights, did not, simply by being recited in the corporate charter issued by the state, become subject to the reserve power, but were protected from impairment by the contract clause of the Federal Constitution just as any other contract between individuals, notwithstanding the reserve power. ${ }^{28}$ The writer admitted that the cases up to that time did not support his analysis. ${ }^{29}$ In his opinion in the instant case, however, he asserts that his view is presently held "by many, if not most, of the courts which have considered the question." 30 But of the nine cases cited in support of this proposition, at least five do not reach the constitutional question. ${ }^{31}$

Further, the tripartite division of the corporate charter is not helpful in the solution of problems. It would be difficult to think of any alteration of the corporate charter by the state that did not affect conditions which the shareholder might reasonably think were part of his bargain with the corporation or his compact with the other shareholders. This difficulty is apparent even in Justice Stern's 1905 article. There, in dealing with the contract between the state and the corporation, he cites with approval a case upholding the power of the state to require a railroad to extend its road beyond the route provided for in the franchise. The justification advanced was that since the state might repeal the franchise altogether, it could impose conditions upon its exercise, the corporation having the alternative of accepting the condition or dissolving. ${ }^{32}$ In treating the contract between the corporation and the shareholders, he criticizes a decision allowing a railroad corporation, under an enabling statute requiring a majority vote of shareholders, to change the termini of the road from those named in the charter over the protest of minority shareholders. The decision is said to be bad because the shareholders had privately agreed upon the termini set forth in the charter and therefore this contract between the shareholders could not be reached by the state's reserve power clause. ${ }^{33}$

27. Id. at 17-19.

28. Id. at 74,75 .

29. Id. at 86 .

30. Schaad v. Hotel Easton Co., 369 Pa. 486, 497, 87 A.2d 227, 232 (1952).

31. Coombes v. Getz, 285 U.S. 434 (1932) (contract was between corporation and third persons; the Court asserts at p. 441, "The corporate charter may be repealed or amended, and, within limits not now necessary to define, the interrelations of state, corporation and stockholders may be changed . . "); Keller v. Wilson \& Co., 21 Del. Ch. 391, 190 At1. 115 (Sup. Ct. 1936) ; Consolidated Film Industries, Inc. v. Johnson, 22 Del. Ch. 407, 197 Atl. 489 (Sup. Ct. 1937) (holding that statute did not confer the power which the corporation attempted to exercise) ; Sutton v. Globe Knitting Works, 276 Mich. 200, 267 N.W. 815 (1936) (statute contained a saving clause similar to that relied on in the instant case); Hueftle v. Farmers Elevator, 145 Neb. 424, 16 N.W.2d 855 (1944) (corporation attempted the change without benefit of a statute.)

32. Stern, supra note 26 , at 21 .

33. Id. at 103. 
Many eminent courts have not adopted the view advanced here by the Pennsylvania court. Typically, in Looker $v$. Maynard ${ }^{\mathbf{8 4}}$ the United States Supreme Court sustained the constitutionality of a statute which gave all corporation stockholders the right to vote their stock cumulatively in the election of directors, although the corporate charter in question was in existence prior to the statute and provided that each share of stock should have but one vote for each director. It has also been held that the legislature or a required number of shareholders may amend so as to alter the capital stock, ${ }^{35}$ shareholders' liability ${ }^{36}$ and the objects and purposes of the corporation. ${ }^{37}$ All these features would be viewed as part of the contract between corporation and shareholder or between the shareholders inter sese.

Probable restrictions on the dictum.-Under present corporation law in Pennsylvania the effect of the holding in the Schaad case as to Pennsylvania corporations organized before 1933 is clear: they will be enjoined from eliminating accrued dividends by direct charter amendment and from effecting other changes in the various rights of stock ownership, not permitted by statutes antedating their existence. The dictum makes it plain that the legislature cannot constitutionally authorize pre-1933 corporations to make such changes. The broad language employed raises the question of whether the dictum does not go even farther and block changes of the rights of shareholders regardless of the date when the corporation was formed. The opinion declares that a state may not amend a corporate charter in respects as to which it constitutes a contract between the corporation and the shareholders or between the shareholders themselves. If the state passes a law permitting less than all of the shareholders to amend the charter in certain respects, as for instance to remove pre-emptive rights or change preferences, the exercise of the power is in effect an amendment of the corporate charter by the state. ${ }^{38}$ As applied to corporations formed after the passage of the statute, the dictum suggests that such action would be unconstitutional since preferences and pre-emptive rights are part of the contract between the corporation and the shareholders. The effect of such reasoning would be to prevent any adjustments of rights among shareholders without unanimous consent. Thus the vote of a few dissenting shareholders could thwart a change in capital structure that might be necessary for the corporation to avoid a financial crisis. ${ }^{39}$

34. 179 U.S. 46 (1900).

35. Haggard v. Lexington Utilities Co., $260 \mathrm{Ky} .261,84$ S.W.2d 84 (1935) ; Pub. Serv. Comm. v. Consolidated Gas, Electric Light \& Power Co., 148 Md. 90, 129 Atl. 22 (1925).

36. Sherman v. Smith, 1 Black 587 (U.S. 1861) ; Farbstein v. Pacific Oil Tool Co., 127 Cal. App. 157, 15 P.2d 766 (1932).

37. Henry v. Markesan State Bank, 68 F.2d 554 (8th Cir. 1934); Picard v. Hughey, 58 Ohio St. 577, 51 N.E. 133 (1898).

38. Stern, supra note 26 , at $77,83$.

39. For example, enjoining the corporation from abrogating redemptive rights would force it to redeem, thus draining off funds vital to the corporation's existence. 
An examination of the opinion in the light of Justice Stern's article, on which the dictum builds, points to the conclusion that this extreme position probably was not intended. The article deals with the power of the state to make or authorize changes in corporate charters under the reserved power. The thrust of the article is that "the reserved power to alter, amend, or repeal a charter is a power reserved by the state as a private party to a contract and not as a sovereign agency of government" 40 and thus cannot extend to the contract among shareholders to which the state is not a party. But this view does not mean that the state, acting in its sovereign capacity quite apart from the reserved power, cannot pass laws regulating the conduct of corporations, including the manner in which future corporations may amend their charters. Assuming that the dictum will be so restricted, constitutional objections based on the contract clause should be no obstacle to corporate action under such statutes, because statutes in existence at the time of formation of the corporation become part of any contract entered into pursuant to the corporation law. ${ }^{41}$

Further limitations in Pennsylvania.-Two remaining problems are presented by the Schaad case. The first is whether the 1933 statute is broad enough to authorize the elimination of accrued dividends by subsequently formed corporations. The opinion does not give a definite answer to the question, but in discussing another Pennsylvania corporation statute ${ }^{42}$ says :

"Merely because a statute may authorize a corporation to refashion its capital structure or reclassify its stock by altering preferential provisions or other terms would not, in the absence of a clear expression of intention to the contrary, warrant an interpretation that would permit the deprivation of dissenting preferred shareholders of their rights in regard to accrued, unpaid, cumulative dividends." 13

It would appear that the court would require an authorization to eliminate accrued dividends to be put in "words of one syllable" as other courts confronted with similar statutes have required. ${ }^{44}$

40. Stern, supra note 26 , at 11 . The author is apparently referring to a situation where the state has a direct interest in the workings of the corporation, such as a railroad, rather than an indirect interest as in the case of a tin can manufacturer.

41. See note 6, supra.

42. PA. STAT. ANn. tit. 15, \$165-166 (Purdon 1938). This act, in general terms, allowed a corporation to refashion its capital structure. It was in effect at the time defendant hotel was incorporated but was repealed before suit was instituted in the instant case. See PA. Stat. ANN. tit. 15, \$223, note (Purdon 1938).

43. Schaad v. Hotel Easton Co., 369 Pa. 486, 495, 87 A.2d 227, 231 (1952).

44. For example in Delaware, following the decision in Morris v. American Public Utilities Co., 14 Del. Ch. 136, 122 Atl. 696 (Ch. 1923), holding that a statute allowing amendment of the corporate charter to change preferences did not authorize elimination of accrued dividends, the statute was amended to allow changes in “. . preferences, or relative, participating, optional or other special rights of the shares. . DEL REv. CODE c. $65 \$ 2058$ (1935). (Italics added). The Supreme Court of Delaware overruled the Chancery Court and ruled that even this language did not empower the corporation to eliminate accrued dividends by charter amendment. Keller v. Wilson \& Co., 21 Del. Ch. 391, 190 Atl. 115 (Sup. Ct. 1936). The Pennsylvania statute is similar to that of Delaware. 
The second question is presented by the limited nature of the Pennsylvania reserve power clause which permits the legislature to amend a corporate charter ". . . whenever in their opinion it may be injurious to the citizens of this Commonwealth, in such manner, however, that no injustice shall be done to the corporators." 45 Thus, even if the court were to retreat from the position apparently taken in the dictum, there would still remain the question whether a particular amendment of the corporate charter, either as it represents a contract between the state and the corporation, or the corporation and the stockholders, complied with these conditions. The court says that whether or not these conditions are met is a judicial question which in the instant case, apart from all other considerations, it would answer in the negative. ${ }^{46}$ Providing the dissenting shareholder with the remedy of appraisal and purchase of his stock would seem to fulfill the requirement of protecting the corporators from injustice; ${ }^{\mathbf{4 7}}$ and there is language from cases in other states to the effect that permitting corporations to shed the burden of dividend arrearages and undertake the financing necessary for survival is a matter of public concern, vital to the economic well-being of the state. ${ }^{48}$ A forceful presentation of this point of view might lead the Pennsylvania court to conclude that this condition to the exercise of the reserve power-no injury to the Commonwealthhad been satisfied. ${ }^{\text {99 }}$

Treatment in other states.-The constitutional question with specific reference to the direct elimination of accrued dividends has been raised in two of the three jurisdictions that have passed statutes explicitly allowing such elimination. ${ }^{50}$ In both instances, the corporations had been formed and had issued stock prior to the statutes and, after passage of the statute,

45. PA. Const., Art. XVI, $\$ 10$ (Purdon 1930).

46. 369 Pa. 486, 498, 87 A.2d 227, 233 (1952).

47. See Note, 57 HaRv. I. REv. 894, 898 (1944), which concludes that the existence of an appraisal remedy would forestall any objection that the elimination of arrearages was an unconstitutional taking of property. This constitutional safeguard would seem analogous to the Pennsylvania protection against injustice to the corporators.

48. E.g., McNulty v. W. \& J. Sloane, 184 Misc. 835, 54 N.Y.S.2d 253 (Sup. Ct. 1945). This court also suggests that whether the amendment is necessary to the public welfare is a matter for the legislature to decide.

49. Note that the Schaad case is dealing with the Pennsylvania Business Corporation Law. This law is not applicable to corporations subject to the supervision of the Department of Banking, the Insurance Department, the Pennsylvania Public Utility Commission, or the Water and Power Resources Board. PA. Stat. AnN. tit. 15, §2852-4(3) (Purdon 1952). The law relating to such corporations permits amendments of the corporate charter in language as broad as the Business Corporation Law and contains no saving clause. However, it gives a dissenting shareholder the remedy of appraisal and payment in all cases of amendments. PA. STAT. ANN. tit. 15, \$224 (Purdon Supp. 1952). This law was passed in 1949 and will present the impairment of contracts problem with respect to most of the existing corporations subject to it. Because of the vital public interest in such corporations, it might be argued that the charter, even as it represents a contract between the corporation and the shareholders, is subject to the reserve power. The same argument would meet the limitation that the reserve power must be exercised only in the public interest.

50. New York, Ohio, and Virginia. The statutes are cited in n. 18, supra. 
attempted to eliminate accrued dividends directly by charter amendment. In McNulty $v . W$. \& J. Sloane, ${ }^{51}$ a New York trial court upheld the constitutionality of the statute as applied to the action in question and, after commenting that the right to accrued dividends is not in the nature of a debt which the shareholder could sue on, said,

"The contract between the stockholder inter sese is not an unconditional contract. It is a contract subject to a condition that it may be changed or altered in the manner prescribed or authorized by the Legislature. Of course, if a right to a specific sum of money has accrued, this right would be preserved against impairment by the constitutional provision protecting property, but that is because this property right exists separate and apart from and in addition to the contract. The very essence of the reserved power of the Legislature is to enable it to change preferential rights of the different classes of stock in a corporation. . . ." 52

\section{The court then added:}

"It is no more unconstitutional to permit the Legislature, under the reserved power, to authorize a corporation to abolish dividends which have accrued in the past, than it is to authorize a corporation to abolish dividends which may accrue in the future. There is a difference in degree, but not one of kind. In both cases there is interference with a contractual relationship between stockholders and the corporation or between the stockholders inter sese. But this the legislature is permitted to do, certainly under the reserved power in the Constitution and in the General Corporation Law, to alter or amend the charters of corporations, if not under the inherent power of the state for the preservation of the general welfare." 53

51. 184 Misc. 835, 54 N.Y.S.2d 253 (Sup. Ct. 1945). This case was cited with approval by the New York Court of Appeals, but in a case involving different issues: Anderson v. International Minerals \& Chemical Corp., 295 N.Y. 343, 351, 67 N.E.2d 573,577 (1946). It was followed in Arstein v. Roberts Reis \& Co., 77 N.Y.S.2d 303 aff'd zeithont opinion 273 App. Div. 963, 79 N.Y.S.2d 314 (1st Dep't), leave to appeal denied, 298 N.Y. 931, 81 N.E.2d 335, cert. denied, 335 U.S. 860 (1948).

52. 184 Misc. 835, 843, 54 N.Y.S.2d 253, 260 (Sup. Ct. 1945).

53. $I d$. at 845,54 N.Y.S.2d at 263 . The court here assumes that there would be no constitutional problems involved in the alteration of the dividend rate for the future or the elimination of the accrual feature for the future without the benefit of a prior statute or charter provision authorizing such action. As a matter of fact, litigation on this point is rare since prior statutes, of which the Delaware statute allowing changes in preferences is typical, have been held to authorize such action. Thus the stockholder has accepted the possibility of such change as one of the terms of his contract and cannot complain. Courts, desirous of protecting the right to accrued dividends, termed it a "vested right" to distinguish it from the right to future cumulative dividends. See, e.g., Morris v. American Public Utilities Co., 14 Del. Ch. 136, 122 Atl. 696 (Ch. 1923) and Keller v. Wilson \& Co., Inc., 21 Del. Ch. 391, 190 At1. 115 (Sup. Ct. 1936). Speculation today as to whether the right to accrued dividends is of a different nature than the right to future dividends is futile. The proper question is whether it is proper to eliminate accrued dividends by the direct, as well as by other, methods and if so under what conditions. 
The opposite result was reached by the Supreme Court of Ohio in Wheatley v. A. I. Root Co. ${ }^{54}$ on the ground that such an application of the statute was an unconstitutional impairment of the obligation of the contract of the preferred shareholders.

Thus a state court confronted with the problem today would have precedent to decide either way. In view of the fact that accrued dividend elimination is permitted by merger and by the indirect method, it seems incongruous to deny, as the Schaad case did, the corporation the power to eliminate accrued dividends by the simplest and most convenient method. The reason for denying the constitutionality of statutes authorizing direct elimination of accrued dividends by corporations in existence prior to the statute is that the reserved power clause, embodied in a statute antedating the corporation, did not give preferred shareholders notice that power to make such a change in the corporate charter was reserved by the state. ${ }^{55}$ But, by the same token, it is equally probable that preferred shareholders did not contemplate that their accrued dividends could be eliminated by merger or by the indirect method. The preferred shareholder probably believed that his accrued dividends would not be subject to impairment. It is unlikely that he even contemplated what his rights would be where the corporation had no earnings and paid no dividends over a period of ten to fifteen years and where a majority or larger percentage of his own class of shares voted in favor of eliminating the accruals due them to enable the corporation to obtain needed working capital. No distinction therefore should be drawn between the three methods on the ground of notice to the shareholder. If elimination is allowed by one method it should be allowed by all three.

\section{A Suggested Approach}

The judicial preoccupation with the questions of corporate power and later with the constitutionality of subsequent statutes has tended to obscure what should be the focal point of such cases-whether the plan adopted is fair to the preferred shareholders. ${ }^{56}$ A finding that power exists in the corporation to effect an elimination of accrued dividends by any of the three methods should not conclude the issue, hiding the fact that the power may

54. 147 Ohio St. 127, 69 N.E.2d 187 (1946). This decision was followed in Schaffner v. Standard Boiler and Plate Iron Co., 150 Ohio St., 454, 83 N.E.2d 192 (1948).

55. This is apparent in such cases as Consolidated Film Industries v. Johnson, 22 Del. Ch. 407, 415, 197 Atl. 489, 493, (Sup. Ct. 1937) and Keller v. Wilson \& Co., 21 Del. Ch. 391, 414, 190 Atl. 115, 126 (Sup. Ct. 1936), which enjoin the plan because the stockholder had not consented to such a term in his contract; and Federal United Corp. v. Havender, 24 Del. Ch. 318, 11 A.2d 331 (Sup. Ct. 1940) and Shanik v. White Sewing Machine Corp., 25 Del. Ch. 371, 19 A.2d 831 (Sup. Ct. 1941), which say that a stockholder should be aware that his accrued dividends might be impaired through merger or issuance of a prior preferred stock, both permitted by statute.

56. In the series of Delaware cases, note 55 supra, no point was made as to whether preferred shareholders were being accorded fair treatment; the issue was simply one of corporate power. In the two cases squarely presenting the constitutional problem, the solution of this issue decided the case with no consideration of what the preferred shareholder was getting in exchange for what he was giving up. 
be exercised mainly for the benefit of common shareholders to the decided disadvantage of preferred shareholders. Nor should generalized statements about the best interests of the corporation or the difficulty of financing when there are heavy arrearages serve to justify the corporate action. ${ }^{57}$ As a matter of fact the idealized picture of the corporation, desiring to eliminate arrearages because it is in need of funds and has only the alternative of issuing common stock open to it, is not always accurate. One authority reports, without elaboration, that not a single instance was found where a recapitalization plan eliminating accruals led to common stock financing. ${ }^{58}$ This statement is rather startling since need for financing is the most common justification given by the courts for allowing accrual elimination ${ }^{59}$ and should lead the courts to consider the problem from a viewpoint other than that of corporate power alone.

The fact that the plan eliminating accruals has the actual approval of at least a majority of the class of shareholders affected and that it seldom appears that more than an insignificant number of preferred shareholders oppose it may allay any feeling on the part of the judiciary that the plan is not fair and ultimately in the best interests of the preferred shareholders. But the protection afforded by the right to vote on the plan is questionable. Directors control the manner in which the plan is presented to stockholders, and in soliciting proxies can emphasize any advantages which the plan is supposed to confer on preferred shareholders, while minimizing its disadvantages. Further, capital impairment is likely to exist where there is a substantial amount of accrued dividends. Under most state corporation laws this will prevent the payment of any dividends, ${ }^{00}$ but the impairment can be corrected by a reduction of capital. This, however, will require the vote of common shareholders, ${ }^{, 1}$ who may refuse to agree to such a reduction unless the preferred shareholders vote to relinguish their accrued dividends. Approval of the. plan by a majority of preferred shareholders, therefore, should not be conclusive in assessing its fairness.

One suggested approach to the problem is that the corporation be required to prove the necessity for the elimination of accrued dividends as a prerequisite for approval of the plan. This would include proof of the need for fresh funds and of a bona fide intention to issue common stock as the method of financing. of the plan is approved. The corporation would also be required to prove that there is no alternative solution of the problem which would have less effect on the relative priorities of the classes of

57. Typical of such generalizations are those found in Hottenstein v. York Ice Machinery Corp., 136 F.2d 944, (3d Cir. 1943); Zobel v. American Locomotive Co., 182 Misc. 323, 44 N.Y.S.2d 33 (Sup. Ct. 1943); Blumenthal v. Di Giorgio Fruit Corp., 30 Cal. App.2d 11, 85 P.2d 580 (1938). (1942).

58. Dodd, Fair and Equitable Recapitalizations, 55 HARv. L. REv. 780, 783

59. See cases cited in note 55 supra.

60. See, for example, PA. Stat. AnN. tit. 15, §2852-701 (Purdon 1938); N.J. Stat. Ann. c. 14 \$8-19 (1939); N.Y. Stock Corporation Law § 58.

61. See, for example, PA. Stat. Ann. tit. 15, §2852-706 (Purdon 1938); Del. REV. CODE $\$ 2060$ (1935). 
stock. ${ }^{62}$ This approach is but a partial solution, for once it is decided that elimination of accrued dividends is necessary, the shifting of future equities in the corporation from the common to the preferred stock is capable of infinite variation. It would have to be annexed to a plan such as that suggested by Professor Dodd, ${ }^{63}$ under which the future earning power of the corporation is estimated to determine whether the junior stock has a reasonable expectation of receiving earnings in the future with the accruals in existence. This possibility of future earnings is then "capitalized" to determine what share of the equity of the corporation the junior stock should be given after accruals are eliminated. While this approach can obtain no more than uncertain predictions, it would have the effect at least of directing the attention of the courts specifically to what preferred shareholders are being forced to surrender and what common shareholders are gaining under accrual elimination plans as they are now being sanctioned.

In addition to the above suggestion, state corporation laws should be amended to give the dissenting shareholder an appraisal remedy under all of the three methods used to eliminate accrued dividends. ${ }^{64}$ Further, courts should refuse to sanction elimination of accrued dividends to the extent that there is presently a surplus available out of which dividends may be paid.

In allowing use of the direct method upon a showing of necessity and fairness, the suggested approach would be more favorable to the corporation than the present law, which results generally in a flat injunction against the plan. This approach would also be more favorable to dissenters than the present law, by permitting them to enjoin merger and optional-method plans unless the corporation demonstrates necessity and fairness, ${ }^{65}$ and by giving dissenters the remedy of appraisal and sale.

Allowing mergers which eliminate accrued dividends, restricting preferred shareholders to the appraisal remedy, is now fairly well entrenched in statute and case law. Excepting this method from the suggested solution might be justified on the ground that mergers are usually attempted to achieve a beneficial union of two going concerns and not solely to eliminate accrued dividends and should be unhampered by suits of minority shareholders protesting the incidental elimination of their accruals. Where, however, the merger is patently a device to effect accrual elimination, as for instance a merger of a parent and inactive subsidiary, it should meet the scrutiny of the suggested solution.

62. Becht, Alterations of Accrued Dividends: II, 49 MrcH. L. REv. 565, 592-594 (1951). (1942).

63. Dodd, Fair and Equitable Recapitalizations, 55 HARv. L. REv. 780, 793-796

64. This is now done under N.Y. Stock Corp. Law $\$ 21$; OHIo Gen. Code AnN. $\$ 8623-14,15,72$ (Supp. 1940). In Pennyslvania the dissenting shareholder is entitled to the appraisal remedy only in cases of merger. See note 2 , supra.

65. Injunctions are not allowed in these situations. See cases cited in notes 10. 11, and 13 supra. 